\title{
A new species of Nuuanu (Amphipoda: Gammaridea: Melitidae) from shallow sandy bottoms of the Balearic Islands (W Mediterranean)
}

\author{
DAMIÀ JAUME and ANTONI BOX \\ IMEDEA (CSIC-UIB), Instituto Mediterráneo de Estudios Avanzados. C/ Miquel Marquès, 21, 07190 Esporles, \\ Illes Balears, Spain. E-mail: d.jaume@uib.es
}

\begin{abstract}
SUMMARY: Nuиапи beatricis $\mathrm{n}$. sp., a new melitid amphipod, is described from shallow-water sandy bottoms on the $\mathrm{S}$ and SE coasts of Mallorca (Balearic Islands, Mediterranean). It differs from the rest of its congeners in the combination of: (1) non-geniculate antennule, much longer than antenna; (2) distal segment of mandibular palp shorter than second, armed with both D and E setae; (3) second segment of mandibular palp with 2 setae; (4) posteroventral lobe (sensu Lowry and Watson, 2002) absent from posterior margin of coxa 4; (5) reduced spine present on medial surface of coxa 5; (6) posterior margin of basis of pereopod 5 convex; (7) anterodistal lobe of coxa 7 wanting; (8) posterior margin of basis of pereopod 7 sparsely serrated along proximal half only; (9) pleonites 1-2 lacking dorsodistal spines; (10) anterodistal corner of epimeral plate 1 rounded; (11) exopod of uropod 3 longer than protopod; and (12) telson with terminal spine on each lobe. Although the new amphipod could be an alien species introduced from a distant tropical location with alien Caulerpa algae species, it is here regarded as an ancient Mediterranean element owing to its peracarid condition (i.e. reduced potential for dispersal), regressed visual apparatus, and crevicular-interstitial existence. The presumed presence of sternal gills in Nuиапи is rejected after demonstration of the coxal origin of the spiniform structures interpreted elsewhere as sternal gills.
\end{abstract}

Keywords: Taxonomy, Crustacea, Peracarida, stygofauna, sternal gills, epipodites.

RESUMEN: Una nueva esPeCie de NuUanu (Amphipoda: Gammaridea: Melitidae) DE Fondos arenosos someros de LAS ISLAS BALEARES (MEDITERRÁNEO OCCIDENTAL). - Nuuanu beatricis $\mathrm{n}$. sp. difiere del resto de congéneres por la combinación de: (1) anténula no geniculada, mucho más larga que la antena; (2) segmento distal del palpo mandibular más corto que el segundo, armado con sedas tipo D y E; (3) segundo segmento del palpo mandibular con 2 sedas; (4) margen posterior de la coxa 4 sin lóbulo posteroventral (sensu Lowry y Watson, 2002); (5) superficie medial de la coxa 5 con una pequeña espina; (6) base del pereópodo 5 con el margen posterior convexo; (7) coxa 7 sin lóbulo anterodistal; (8) base del pereópodo 7 con el margen posterior serrado laxamente sólo a lo largo de la mitad proximal; (9) pleonitos 1-2 sin espinas dorsodistales; (10) placa epimeral 1 con el extremo anterodistal redondeado; (11) urópodo 3 con el exópodo más largo que el protópodo; y (12) telson con una espina terminal sobre cada lóbulo. Aunque podría tratarse de una especie tropical introducida recientemente en el Mediterráneo junto con especies también alóctonas de alga Caulerpa, es más probable que la nueva especie se corresponda con un elemento paleomediterráneo dada su condición peracárida (que conlleva un bajo potencial dispersivo), la regresión de su aparato visual, además de su ligazón al medio crevicular-intersticial. Se descarta la supuesta presencia de branquias esternales en Nииапи tras demostrarse el origen coxal de de las estructuras espiniformes interpretadas hasta ahora como tales.

Palabras clave: Taxonomía, Crustacea, Peracarida, estigofauna, branquias esternales, epipoditos.

\section{INTRODUCTION}

Nuиanu is a genus of melitid amphipods comprising 10 mostly shallow-water species known from tropical and warm-temperate seas, with species distributions usually restricted to a single locality. Records of this genus appear scattered through the Hawaiian Islands, Micronesia, E 
Australia, Andaman Islands, Madagascar, SE Africa, W Mediterranean, and the Caribbean in anchialine caves, marine macroporous interstitial environments, or exceptionally in the deep-sea. The genus is considered to be of tropical affinity and Tethyan origin, although N. castellana (Griffiths, 1977) was reported from deep muddy bottoms (at $550 \mathrm{~m}$ depth) off the east coast of South Africa (Martí and Villlora-Moreno, 1995). Here we describe a new species associated with coarse sandy sediments in shallow waters of the Balearic Islands. In the Mediterranean, there was a previous report of the genus, Nuuanu garciai (Martí and Villora-Moreno, 1995), from coarse sandy bottoms at Chafarinas Islands (northern Moroccan coast). The only other gammarellid (sensu Lowry and Watson, 2002) known from the area is Gammarella fucicola (Leach, 1814), which is widely distributed along the Mediterranean and NE Atlantic coasts, and present also at the Balearic stations that rendered the new species described herein.

The new taxon was gathered in the framework of a research project aiming to evaluate the effects of the colonisation of the rhizomes of the seagrass Posidonia oceanica Delile by the macroalgae Caulerpa prolifera (Forsskal) J.V. Lamoroux (native), and the alien tropical Caulerpa racemosa (Forsskal) J. Agardh and C. taxifolia (M. Vahl) C. Agardh. It is possible that the new amphipod could be an alien species introduced from a distant tropical location with the alien algae, but we prefer to regard it as an ancient Mediterranean element because its peracarid condition, regressed visual apparatus, and crevicular-interstitial existence all suggest a significantly reduced potential for dispersal.

\section{MATERIAL AND METHODS}

Nuuanu beatricis n. sp. was collected at Portals Vells cove (Calvià, Mallorca, Balearic Islands) at 3 $\mathrm{m}$ depth among Posidonia oceanica rhizomes colonised by Caulerpa racemosa. It was also gathered at Cala d'Or cove (Santanyí; Mallorca) at 4-8 m depth among Posidonia oceanica rhizomes colonised by Caulerpa taxifolia and Caulerpa prolifera. Collection of specimens was performed using a $20 \times 20 \mathrm{~cm}$ frame set by scuba-diving in the rhizome bed down to 5 centimetres depth; both sediment and rhizomes inside the frame were removed and placed in a net-bag of $200 \mu \mathrm{m}$ mesh size, which was transferred to a plastic flask with seawater for transport to the laboratory, prior to fixation with formalin. Sediment at Portals Vells consisted of biogenic medium sand (mean grain size: $250 \mu \mathrm{m}$ ), whereas at Cala d'Or the mean grain size of the sand was smaller (125-250 $\mu \mathrm{m})$. Once in the laboratory, the amphipods were sorted under the stereomicro-

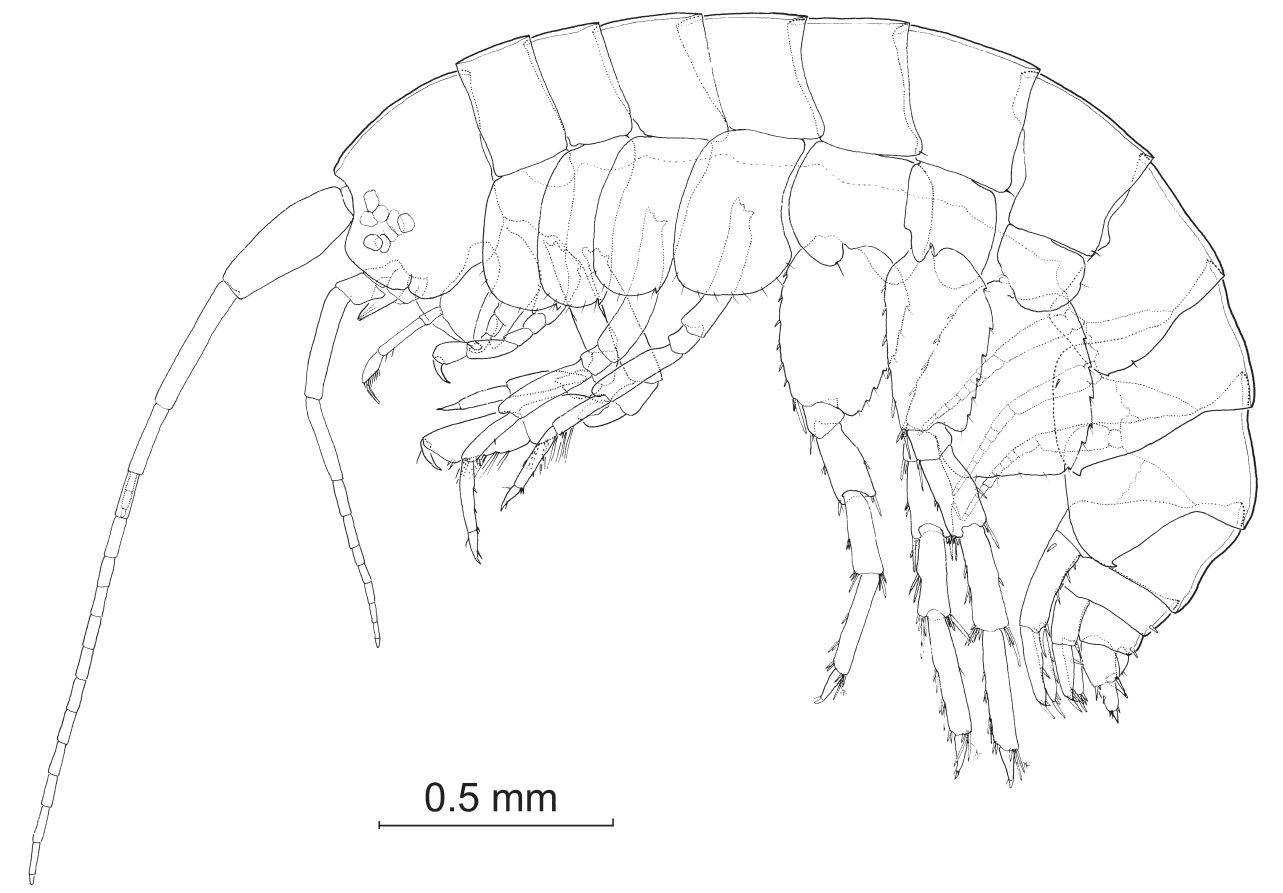

FIG. 1. - Nuиanu beatricis n. sp., habitus of brooding female holotype (coxal gills and oostegites omitted). 
scope and their internal tissues were partially digested with lactic acid to facilitate observation. Drawings were prepared using a camera lucida on an Olympus BH-2 microscope equipped with Nomarski differential interference contrast. Body measurements were derived from the sum of the maximum dorsal distances of somites and exclude telson length. Appendages preserved in permanent slides were mounted in lactophenol and the coverslips sealed with nail varnish. The materials are deposited in the Crustacea collection of The Natural History Museum, London [BMNH].

\section{TAXONOMY}

Suborder GAMMARIDEA

Family Melitidae Bousfield, 1977

Genus Nuиапи J.L. Barnard, 1970

emend. Lowry and Watson, 2002

Nuuanu beatricis $\mathrm{n}$. $\mathrm{sp}$.

(Figs. 1-10)

Material examined. Portals Vells, Calvià, Mallorca (Balearic Islands); UTM coordinates (Datum Europe 50): 4369557 / 31 459026. HOLOTYPE: brooding female (oostegites developed, setose) $3.59 \mathrm{~mm}$ [BMNH reg. no. 2006.359]; PARATYPES: male $2.48 \mathrm{~mm}$ with left second gnathopod dissected and mounted on sin-

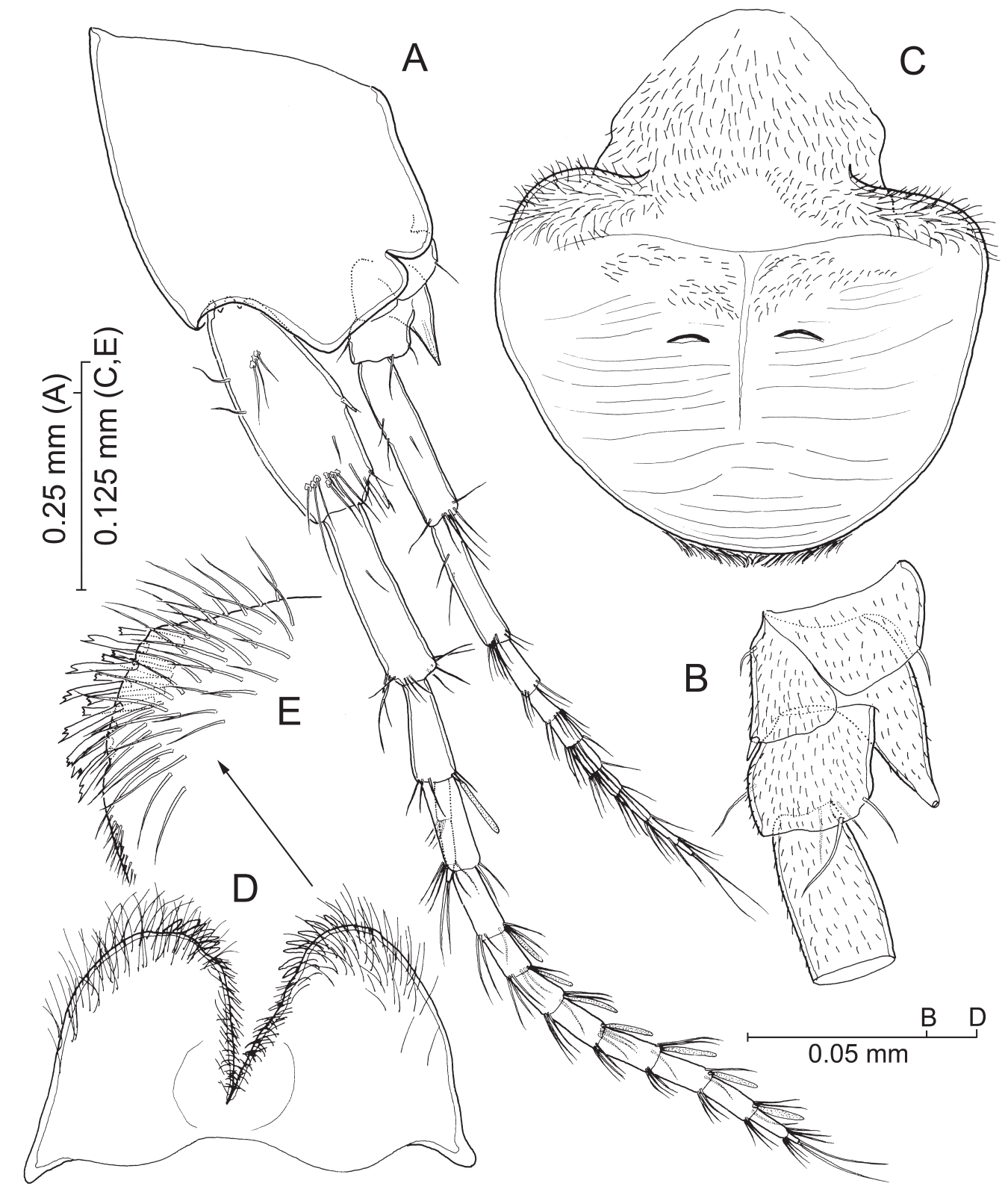

FIG. 2. - Nииапи beatricis n. sp., female holotype. A, head with left antennule and antenna attached, lateral; B, detail of proximal portion of left antennal peduncle, lateral; C; labrum, anterior; D, paragnaths, anterior; E, detail of distomedial portion of right paragnath, anterior. 


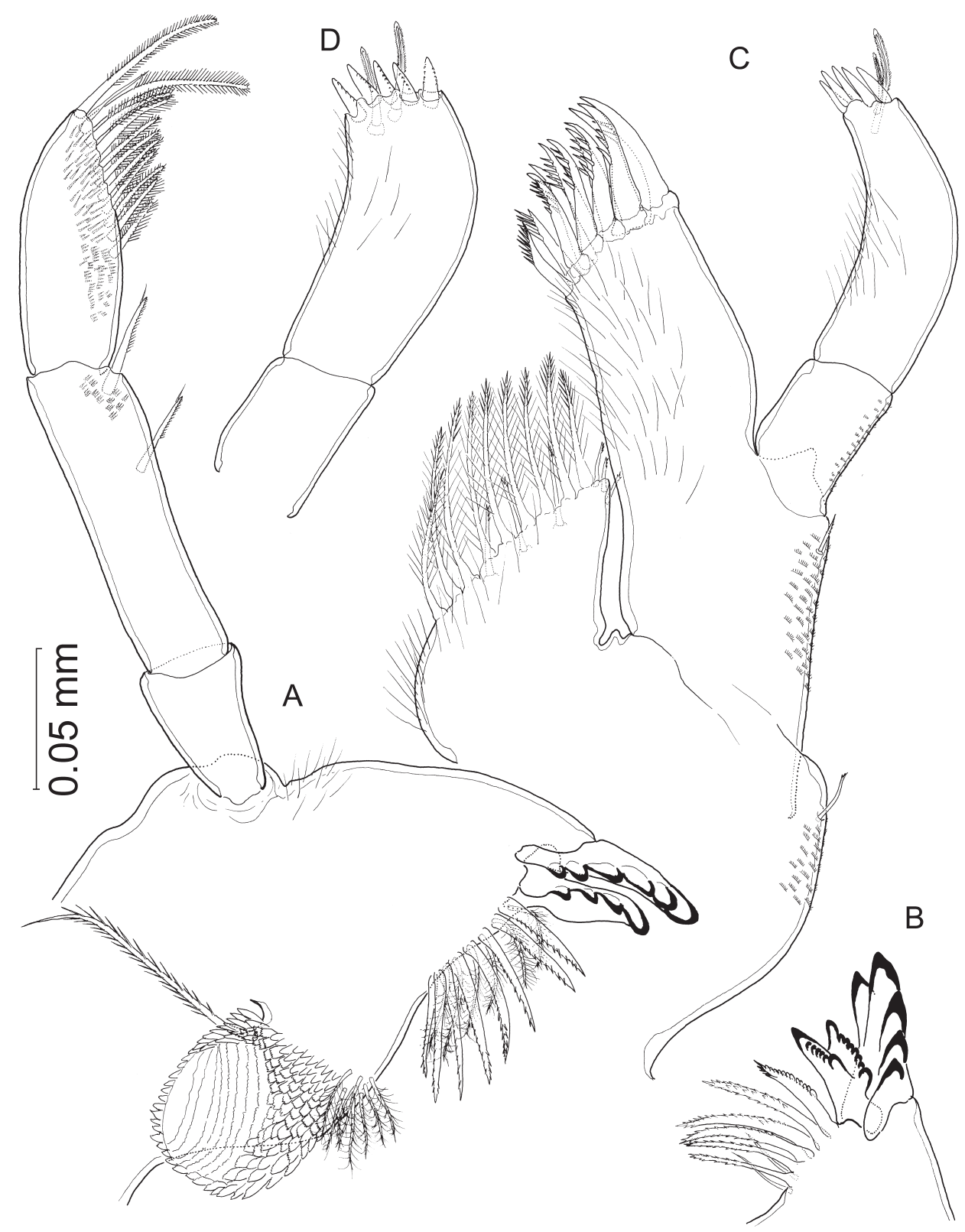

FIG. 3. - Nuиanu beatricis $\mathrm{n}$. sp., female holotype. A, left mandible, medial; B, detail of incisor, lacinia mobilis and spine row of right mandible, medial; C, left maxillule, medial; D, detail of endopod of latter, anterior.

gle slide; 2 females without oostegites, $3.25 \mathrm{~mm}$ (completely dissected and mounted on single slide) and $2.81 \mathrm{~mm}$; other 2 female specimens partially damaged, not measured [BMNH reg. nos. 2006.360-364].

Diagnosis. Antennule non-geniculate, much longer than antenna. Distal segment of mandibular palp shorter than second, armed with both $\mathrm{D}$ and $\mathrm{E}$ setae. Second segment of mandibular palp with 2 setae. Posteroventral lobe (sensu Lowry and Watson, 2002) on posterior margin of coxa 4 wanting. Reduced spine present on medial surface of coxa 5. Posterior margin of basis of pereopod 5 con- vex. Anterodistal lobe of coxa 7 wanting. Posterior margin of basis of pereopod 7 sparsely serrated along proximal half only. Pleonites 1-2 lacking dorsodistal spines. Anterodistal corner of epimeral plate 1 rounded. Exopod of uropod 3 longer than protopod. Telson with terminal spine on each lobe.

Description of female. Body (Fig. 1) compact, with integument of somites and most limbs densely caespitose (e.g. Figs. 2B; 5; 7; 8A, D, F; 9A; 10A, $\mathrm{F}$; integumental ornamentation omitted from rest of figures); tiny surface spinules with truncate tip observable at high magnification (not figured). Head 
(Fig. 2A) with obtuse triangular lateral cephalic lobes and with deep anteroventral notch. Eyes hardly developed, with separated ommatidia (Fig. 1). Pleonites lacking dorsodistal spines (Fig. 1). Epimeral plates 1-3 (Fig. 9A) with evenly-rounded anteroventral corner and pointed posteroventral corner; ventral margin of epimeral plate 1 straight, margins of plates 2-3 convex; posterior margin of plate 1 strongly convex, those of plates 2-3 slightly con- vex; short and stout seta present submarginally close to anteroventral corner of plate 2 ; posterodistal corner of plate 3 variably produced, from falcate in smaller specimens (including male; Fig. 9B) to less produced in bigger specimens (Fig. 9A) . Urosomite 1 without dorsal keel; urosomites 2-3 with posterodorsal spine at each side (Fig. 10A).

Antennule (Fig. 2A) non-geniculate, longer than antenna, with 3-segmented peduncle, 10 to 13 -artic-

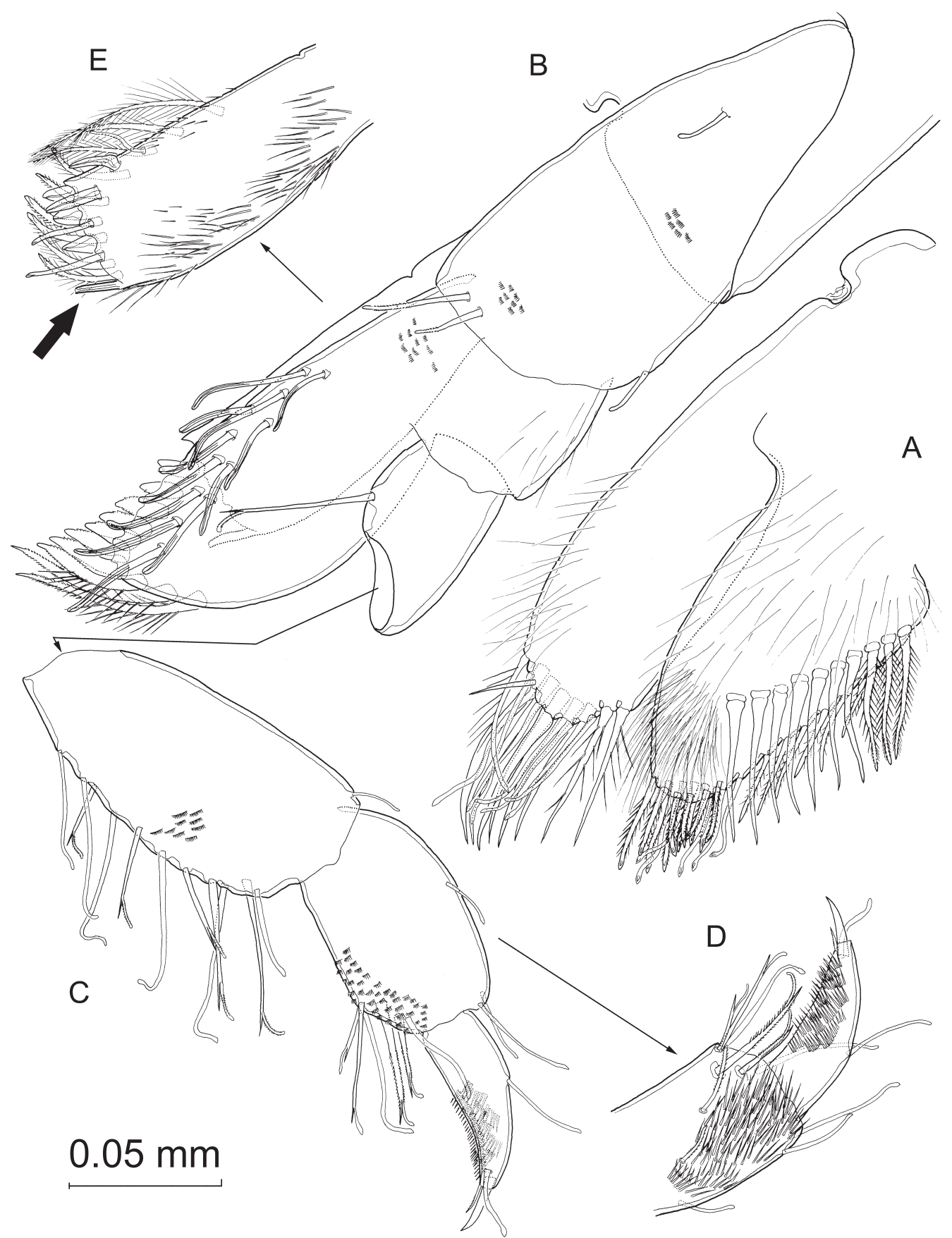

FIG. 4. - Nuиапи beatricis n. sp., female holotype. A, right maxilla, anterior (ornamentation of several setae of oblique row on coxal endite omitted); B, right maxilliped with endopod partially disarticulated, posterior; C, carpus to dactylus of latter, posterior; D, detail of ornamentation of propodus and dactylus, anterior; E, detail of maxillipedal basal endite (arrow points to outlet of gland). 


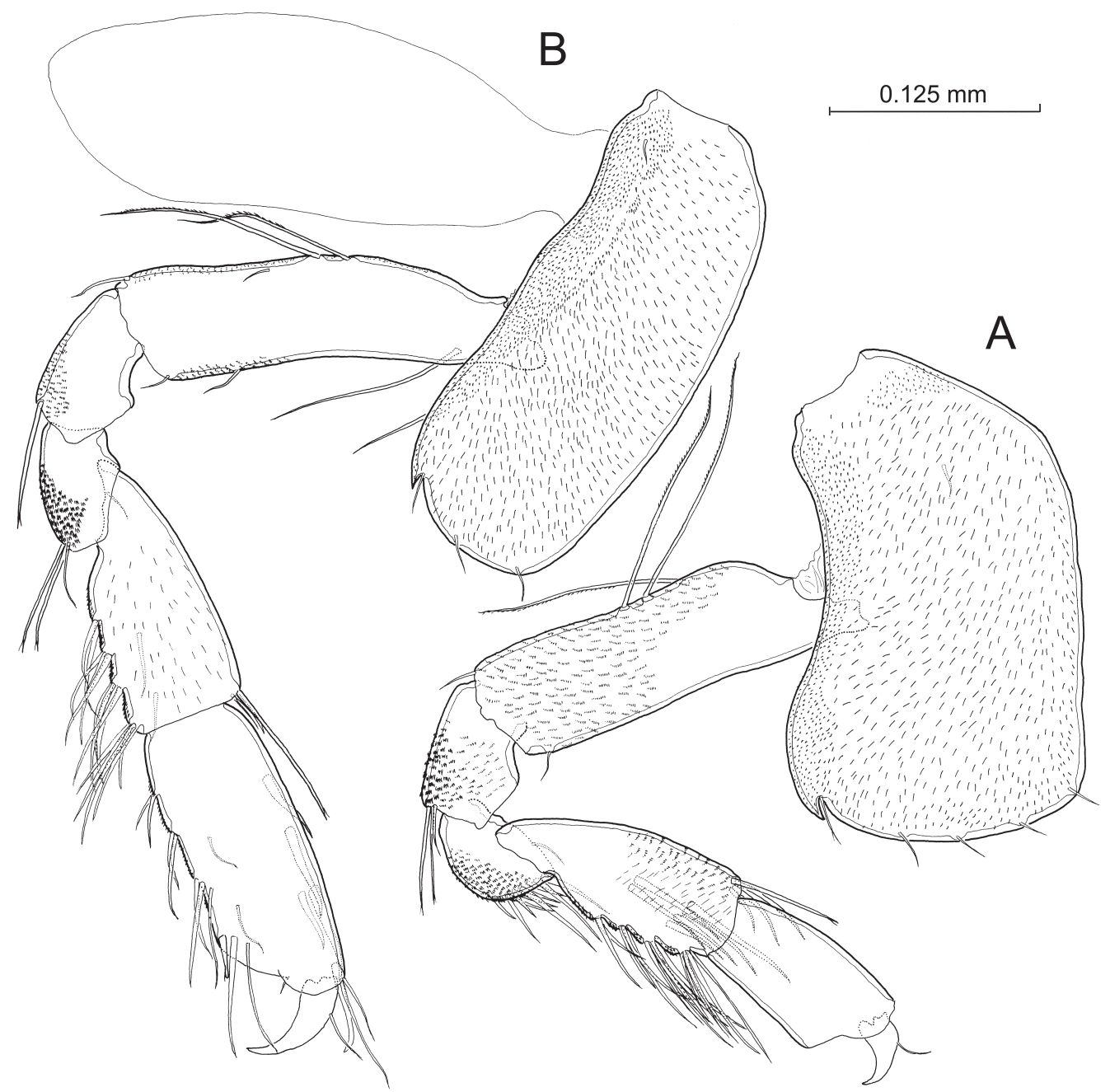

FIG. 5. - Nuиапи beatricis n. sp., female holotype. A, right first gnathopod, lateral; B, right second gnathopod, lateral. Armature of distal segments of both limbs partially outlined only (see Fig. 6 for details of ornamentation and armature of these segments).

ulate main flagellum and 3-articulate accessory flagellum. First peduncle segment longer than segment 2 , with 2 stout spines on posterior margin. Single aesthetasc on third peduncle segment and on $2^{\text {nd }}$ to $8^{\text {th }}$ articles of main flagellum.

Antenna (Fig. 2A) with 5-segmented peduncle and 8-articulate flagellum; second peduncle segment not produced dorsodistally, with short spine (Fig. 2B); gland cone acute. Flagellum about as long as 4 proximal peduncle segments taken together.

Labrum (Fig. 2C) globose with short epistome; 2 slits present on anterior surface. Paragnaths (Fig. 2D) with 2 sub-parallel rows of flattened hyaline spines with serrate tips on outer lobes; spines comprising posterior row smaller (Fig. 2E). Inner lobes wanting.

Left Mandible (Fig. 3A) with 6-cuspidate incisor and 4-cuspidate lacinia mobilis, latter similar in appearance and orientation to incisor process; basis of lacinia developed as articular condyle associated with incisor, which acts as articular socket. Spine row comprising 8 denticulate elements; row of 6 pappose slender setae running parallel to spine row on lateral side; molar process truncate, columnar, with patch of short, pappose slender setae basally on anterior margin, and long denticulate molar seta on posterior margin; grinding surface comprising series of parallel, sclerotised serrate ridges. Palp 3-segmented, second segment longest, with 2 unipinnate setae on distal half of anterior margin; distal segment about $75 \%$ length of preceding segment, with 9 stout, bipinnate D-setae with rounded tip and $3 \mathrm{E}-$ setae, one of which smooth and reduced. Right Mandible (Fig. 3B) with 5-cuspidate incisor and articulated lacinia, latter bifurcate, distal branch 8cuspidate, proximal branch 7-cuspidate; spine row comprising 6 spinulose elements, distalmost with row of rounded denticles similar to those of lacinia 


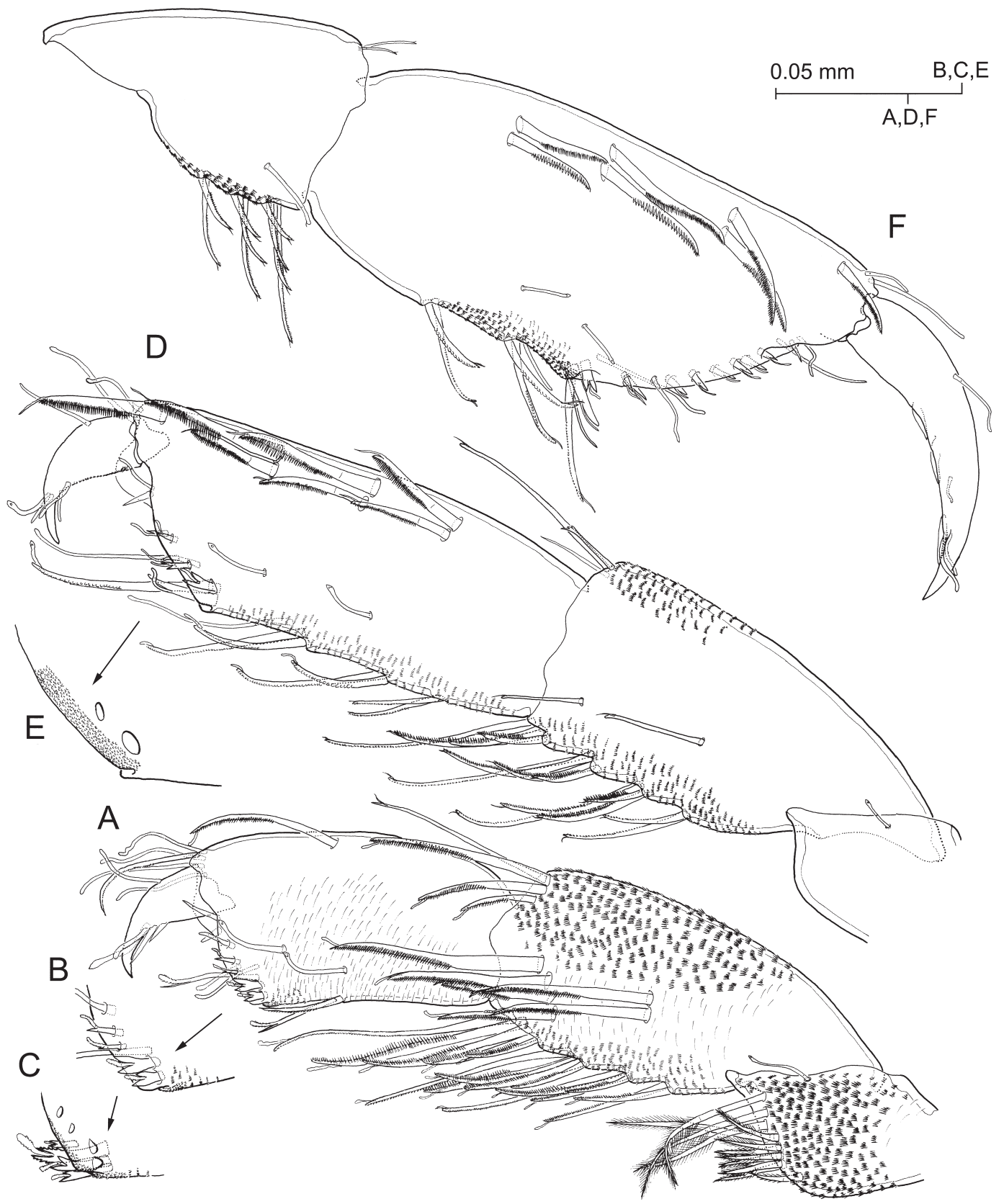

FIG. 6. - Nииапи beatricis $\mathrm{n}$. sp. A, detail of distal portion of first gnathopod of female holotype, medial (lateral armature of palm angle omitted); B, detail of medial armature of palm angle; C, detail of lateral armature of palm angle; D, detail of distal portion of second gnathopod of female holotype, medial; E, detail of palm margin integumental ornamentation, medial; F, detail of distal portion of second gnathopod of male paratype, medial.

on one margin; 2 short pappose slender setae disposed on lateral margin of spine row as figured.

Maxillule (Fig. 3C) coxal endite subtriangular with row of 9 stout bipinnate setae along medial margin and 3 shorter spines with multicuspid tip submarginally; 3 short spines subdistally close to unarmed tip of endite. Basal endite with $6+5$ distal arrangement of stout denticulate spines. Endopod (= palp) bisegmented, distal segment with 5 short and stout distal spines, plus 2 setae with expanded rounded tip subdistally as in Fig. 3D. Outer margin of coxa and basis each with short seta close to distal corner.

Maxilla (Fig. 4A) coxal endite (= inner lobe) with oblique row of 10 stout setae on anterior surface and 6 short spines along medial margin. Basal endite (= outer lobe) with 1 stout curved spine distally and transverse row of 5 additional stout curved spines subdistally on posterior surface of segment. Rest of armature on both endites as figured. 


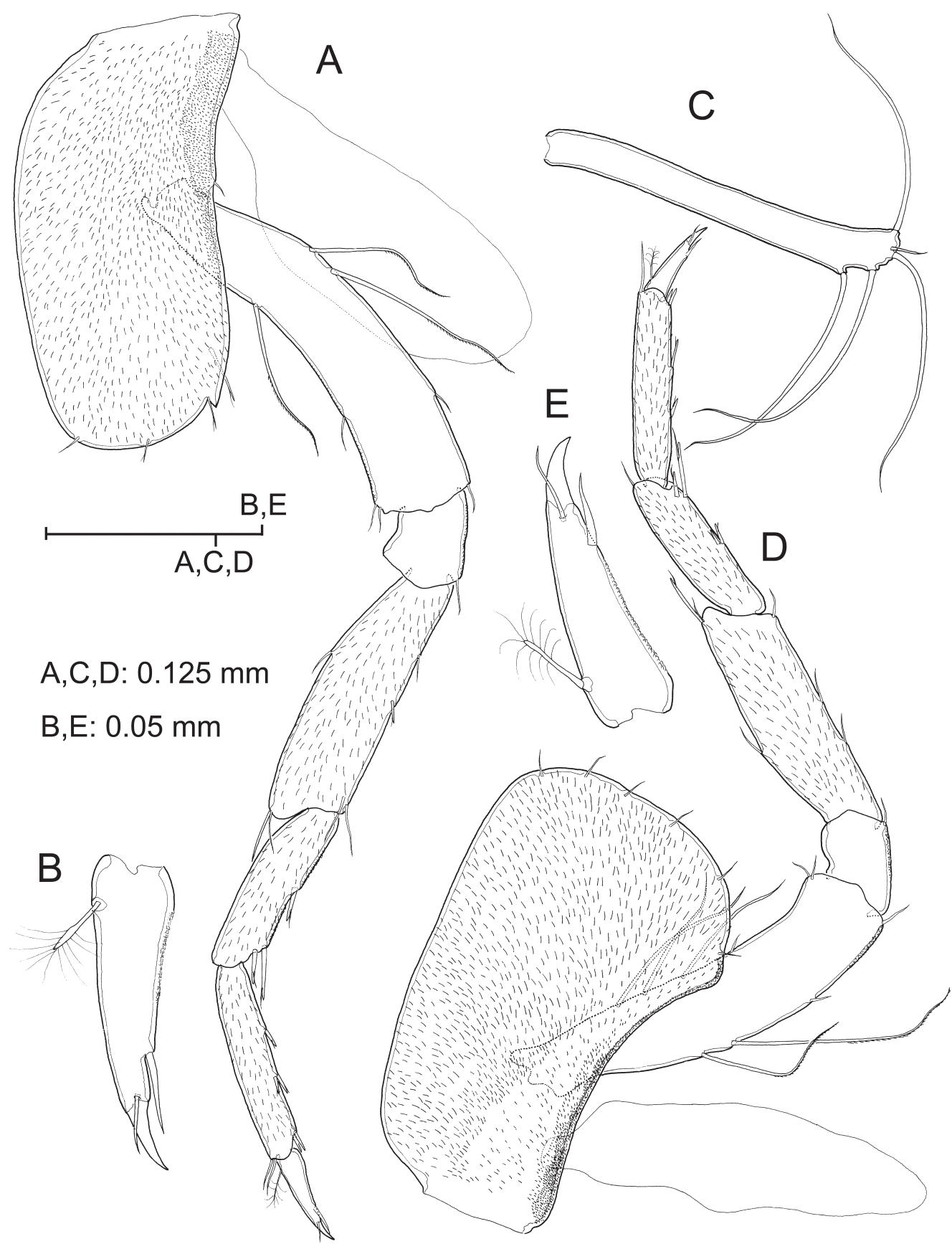

FIG. 7. - Nuиапи beatricis n. sp. A, left pereopod 3 of female holotype, lateral; B, detail of nail (dactylus + unguis); C, oostegite on pereopod 3 of brooding female paratype; D, right pereopod 4 of female holotype, lateral; E; detail of nail.

Maxillipeds (Fig. 4B) with fused coxae unarmed. Basis with 1 short seta close to distolateral corner and 3 setae on posterior surface of segment. Basal endite (= inner plate; Fig. 4E) subrectangular, with 2 smooth spines and 3 smooth setae on posterior surface; curved row of 9 spinulose setae on anterior surface, setae progressively shorter and stouter towards distolateral corner of endite, latter occupied by tubular outlet of unidentified gland (arrowed in Fig. 4E); distal margin of endite with 3 smooth stout spines on medial half. Ischium unarmed; ischial endite (= outer plate) reaching halfway along carpus (= second palp segment), with 7 denticulate stout spines along distomedial margin; 3 longer and more slender spines, spinulose proximally and denticulate distally, on distolateral margin; cluster of about 12 smooth setae with rounded tip and presumably with pore terminally disposed submarginally close to medial margin on posterior surface of endite. Merus, carpus, propodus and dactylus (together comprising 
so-called palp) with relative proportions of segments as in Figure 4B-C; patch of densely-set spinules on anterior surface of both propodus and dactylus as in Figure 4D.

Coxal gills on gnathopod 2 (Fig. 5B) and pereopods 3 to 6 (Figs. 7A, D; 8A, B, D), smooth, ovoid, hardly stalked. Oostegites (Fig. 7C) on second gnathopod and pereopods 3 to 5, narrow, with about 4 long setae and single short seta distally.
Gnathopods reduced compared to rest of pereopods (Fig. 1). Coxal plate of gnathopod 1 (Fig. 5 A) about twice as long as wide, roughly romboid due to strongly convex anterior margin; posterior margin deeply concave; posterodistal corner notched. Carpus longer than propodus, latter subchelate, with palm angle at about $75 \%$ maximum (= anterior margin) length of segment, bearing 2 flagellate bifid spines on medial side (Fig. 6B) and 4 flagellate bifid spines on

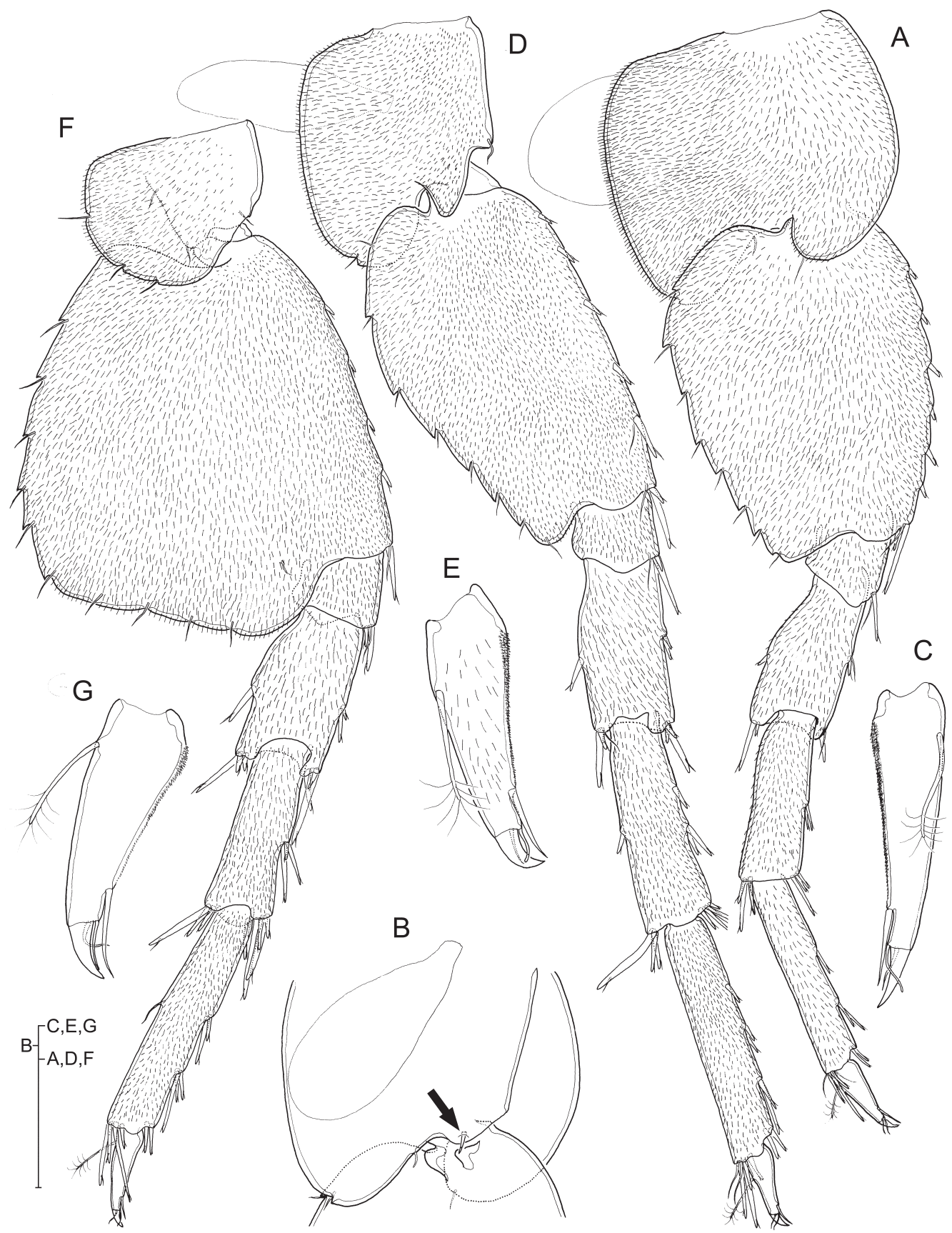

FIG. 8. - Nuиanu beatricis n. sp., female holotype. A, right pereopod 5, lateral; B, detail of medial surface of coxa of left pereopod 5 (arrow points to "sternal gill" spine); C, detail of nail; D, right pereopod 6, lateral; E, detail of nail; F, right pereopod 7, lateral; G, detail of nail. Scale bars: $0.125 \mathrm{~mm}(\mathrm{~A}, \mathrm{~B}, \mathrm{D}, \mathrm{F}) ; 0.05 \mathrm{~mm}(\mathrm{C}, \mathrm{E}, \mathrm{G})$. 


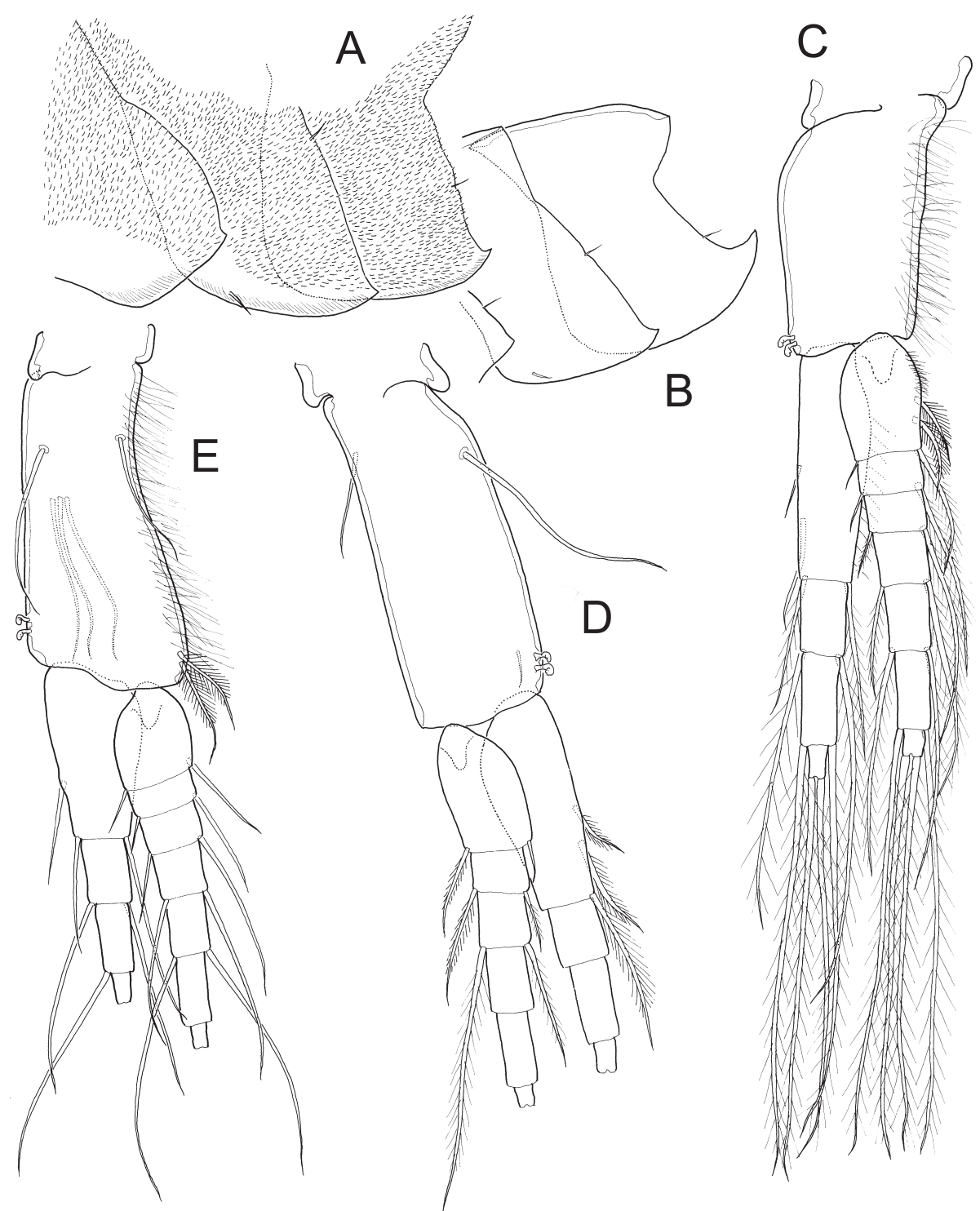

FIG. 9. - Nuиапи beatricis $\mathrm{n}$. sp. A, left epimeral plates of female holotype, lateral; same for male paratype (integumental ornamentation omitted); C, left pleopod 1 of female holotype, anterior; D, right pleopod 2, anterior (setae on distal articles of rami omitted); E, left pleopod 3 , anterior (setae on distal articles of rami and ornamentation of all ramal setae omitted).

lateral side (Fig. 6C); rest of armature on segments as in Figures 5A and 6A. Gnathopod 2 (Fig. 5B) larger than gnathopod 1 , with narrow subrectangular coxal plate, about 2.4 times longer than wide, posterodistal corner notched; merus subquadrate posterodistally (Fig. 6D); carpus and propodus equal in length, propodal palm angle placed at about $71 \%$ maximum length of segment, with short flagellate bifid spine on medial margin and strong flagellate unicuspid spine on lateral margin; integument of palm margin microtuberculate (Fig. 6E). Rest of armature on segments as in Figures $5 \mathrm{~B}$ and $6 \mathrm{D}$.

Pereopods 3-4 slender, pereopod 3 longer than 4 due to longer basis and merus. Pereopod 3 (Fig. 7A) coxa 2.1 times longer than wide, with convex ante- rior margin and shallowly excavate posterior margin, posterodistal corner notched; merus longer than carpus, and this shorter than propodus; claw (= dactylus + unguis) slender, dactylus with 2 smooth setae distally and one penicillate seta proximally on anterior margin (Fig. 7B). Pereopod 4 (Fig. 7D, E) similar to preceding limb except for coxa and for presence of more long marginal setae on basis; coxa expanded distally and with deeply concave posterior margin lacking so-called posteroventral lobe (Lowry and Watson, 2002).

Pereopods 5-7 with claws progressively shorter and more robust from $5^{\text {th }}$ to $7^{\text {th }}$ (compare Fig. $8 \mathrm{C}, \mathrm{E}$ and $G$ ), each with 3 distal smooth setae and proximal penicillate seta on dactylus. Pereopod 5 (Fig. 


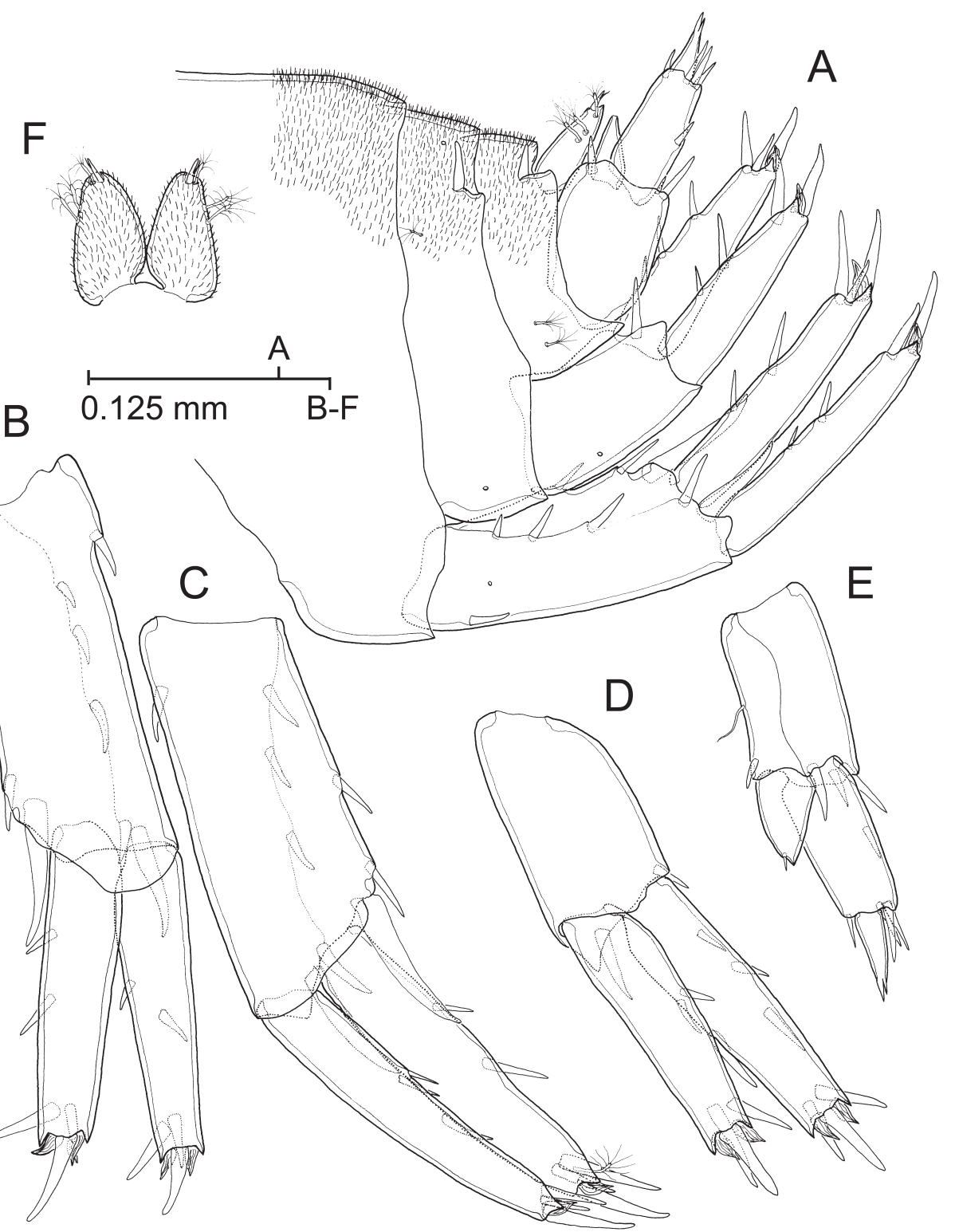

FIG. 10. - Nuиапи beatricis $\mathrm{n}$. sp., female holotype. A, detail of urosome and telson, lateral (integumental ornamentation represented only on dorsal surface of urosomites and telson); B, left uropod 1, anterior; C, right uropod 1, medial; D, right uropod 2, anterior; E, right uropod 3 , posterior; F, telson, dorsal (= posterior). Integumental ornamentation of uropods omitted.

8A) coxa about as long as wide, with evenly rounded anterior margin and slightly convex, almost straight posterior margin; equilobate: anterodistal lobe evenly rounded, not outreaching posterodistal lobe of segment; tiny spine (arrowed in Fig. 8B) present in homologous position to structure interpreted as putative sternal gill in other congeneric taxa (e.g. Vonk, 1988). Basis about 1.3 times longer than broad, posterior margin sparsely serrated, with triangular posterodistal lobe.

Pereopod 6 (Fig. 8D) longest, with anterior margin of coxa straight, posterior margin slightly con- cave; coxa bilobate, anterodistal lobe triangular, separated from anterodistal corner of segment by wide notch, slender, not outreaching evenly rounded posterodistal lobe. Basis slender, about 1.7 times longer than broad, with sparsely serrated posterior margin and well-developed, evenly rounded posterodistal lobe.

Pereopod 7 (Fig. 8F) with coxa unilobed, anterodistal lobe wanting. Basis widely expanded posteriorly, plate-like, sparsely serrated only along proximal half of posterior margin, about 1.2 times longer than wide; posterodistal lobe evenly rounded. 
Pleopods (Fig. 9C-E) biramous, untransformed, protopods with pair of retinacles close to distomedial corner, and with presumed traces of intersegmental articulation proximally; nevertheless muscle signature not supporting subdivision of segment into coxa and basis. Outer margin of protopod of pleopods 1 and 3 with setulose outer margin, that of pleopod 2 apparently smooth. Protopod of pleopod 1 unarmed and slightly shorter than rest (Fig. 9C); that of pleopod 2 with 1 seta on anterior and 1 on posterior surface of segment (Fig. 9D); protopod of pleopod 3 with 2 setae on anterior surface and cluster of 3 setae on posterior surface of segment (Fig. 9E). Rami of pleopods about equal in length to corresponding protopod except pleopod 1, with rami longer than protopod.

Uropods progressively shorter towards posterior (Fig. 10A). First uropod (Fig. 10B, C) protopod with basofacial spine, 2-3 spines on outer margin, and 2 spines on inner margin; 2 unequal spines present on outer distal corner and 1 on inner distal corner of segment. Rami about equal in length, slightly shorter than protopod. Exopod with 1 spine at each margin; tip of segment with long spine and short penicillate seta flanged by 1 spine and 1 striated hyaline spinelike process at each side. Endopod similar to exopod except for presence of 2 spines on inner margin, 0-1 on outer margin, and absence of terminal penicillate seta. Second uropod (Fig. 10D) protopod shorter than rami, with 1 spine at each distal corner, inner spine shorter. Exopod shorter than endopod, with 1 short spine on inner margin and smooth outer margin; 1 stout spine flanged with 1 spine and 1 striated hyaline, spine-like process at each side on tip of segment. Endopod with 2 spines on outer margin and 3 on inner margin; tip of segment with same armature as exopod. Third uropod (Fig. 10E) protopod with 2 unequal distal spines on anterior margin and single distal spine on posterior margin; 1 seta and 1 distal spine on medial margin of segment as figured. Exopod biramous, proximal segment longest, about as long as protopod, with single spine about midway of outer margin and 3 unequal spines distally; inner margin of segment with single spine distally. Distal segment about one-half length of preceding segment, tapering into bifid process. Endopod triangular, less than one-half length of proximal exopodal segment, with tiny subdistal spine. Telson (Fig. 10F) completely cleft, slightly broader than long, each lobe with 2 penicillate setae at about two-thirds of distance on outer margin, and another pencillate seta plus spine on tip.
Description of male. Apparently smaller than female (body length of single specimen available $2.48 \mathrm{~mm}$ ). Identical in all respects to female except for second gnathopod (Fig. 6F), with comparatively shorter carpus (especially posterior margin of segment), and more oblique palm margin of propodus (palm angle at $57 \%$ length of segment). In addition, palm displaying higher number of unicuspid flagellar spines, and dactylus with 3 laminar spine-like processes on posterior margin, absent in female. Paired penile papillae not figured.

Etymology. Species named after our laboratory colleague, Beatriz Morales Nin.

Remarks. The new taxon conforms precisely to the genus Nuиanu as recently redefined by Lowry and Watson (2002) based on the small body size, the poorly-developed eyes, the 3-articulate accessory flagellum, and the absence of dorsal keel on the first urosomite. Of the 10 species comprising the genus, only Nuиanu garciai shares with the new taxon the absence of dorsodistal spines on pleonites 1-2 and of posteroventral lobe on the posterior margin of coxa of pereopod 4. But the new species differs strikingly in other features. Namely: (1) second segment of mandibular palp with 2 setae (unarmed in garciai), (2) third segment with several D and 3 E setae (armature reduced to only $2 \mathrm{E}$ setae in garciai), (3) posterior margin of basis of pereopod 5 convex (shallowly excavated in garciai), (4) exopod of third uropod clearly longer than protopod (versus much shorter than protopod in garciai), and (5) telson with 1 distal spine on each lobe (unarmed in garciai), to mention only the most conspicuous differences.

The tiny spine present on the medial surface of coxa 5 (Fig. 8B) of the new species is similar, although more reduced, to that displayed in homologous position by Nuuanu curvata Vonk, 1988, which was tentatively considered by the latter author as a sternal gill. Vonk (1988) mentions that it is displayed also by Nuиanu numbadi (Barnard, 1970) and by Nuиanu muelleri Ortiz, 1976, although the original description of the latter species (Ortiz, 1976) does not show or mention anything about this. Descriptions of other Nuиanu species do not indicate whether this structure is present or not. Schellenberg (1930) was first to distinguish in amphipods gills directly attached to the ventral part of the body ("Sternalkieme") from the ordinary coxal ("Coxalkieme") gills. It is worth mentioning 
that, at least in the new species, the spine is placed on the coxa and not on the sternite, and consequently it is hardly comparable to a true sternal gill. Even its form as an ordinary spine differs from those of sternal gills (see, for example, those figured in Ueno (1966: 511), or Holsinger (1977: 272). Sternal gills are reported to occur in amphipods of many families (e.g. Crangonyctidae Bousfield, 1973; Pseudocrangonyctidae Holsinger, 1989; Paramelitidae Bousfield, 1977; Neoniphargidae Bousfield, 1977; Hyalellidae Bulycheva, 1957; Paracrangonyctidae Bousfield, 1982; Bogidiellidae Hertzog, 1936), but we interpret the spiniform structure present on the medial surface of coxa 5 of some Nuиапи species as an ordinary spine. The presence of setae or spines on the medial surface of other pereopodal coxae of the new species lends additional support to this interpretation (notice, for example the tiny seta present proximally on the medial surface of coxae 1 and 2 (Fig. 5A, B), the slender subdistal flagellate spine on coxa 3 (Fig. 7A), or the 3 setae on coxa 7 (Fig. 8F).

\section{ACKNOWLEDGEMENTS}

This work was supported by the project CAULEXPAN (REN2002-00701, Spanish Ministry of Science and Education) and the Taxonomic Clearing Facility of the EU Network of Excellence MARBEF.

\section{REFERENCES}

Barnard, J.L. and C.M. Barnard. - 1983. Freshwater Amphipoda of the World. Vol. I. Hayfield Associates, Virginia.

Holsinger, J.R. - 1977. A review of the systematics of the Holartic amphipod family Crangonyctidae. Crustaceana Suppl., 4: 244281.

Lowry, J. and M. Watson. - 2002. Revision of the Gammarellid group, with new species from the Andaman Sea (Crustacea, Amphipoda, Melitidae). Phuket mar. biol. Centre Spec. Publ., 23(1): 197-212.

Martí, A. and S. Villora-Moreno. - 1995. A new interstitial species of Gammarella (Amphipoda, Gammaridea) from the western Mediterranean Sea. Contrib. Zool., 65: 18-200.

Ortiz, M. - 1976. Un nuevo anfípodo (Amphipoda, Gammaridea, Gammaridae) colectado del contenido estomacal del Ronco Amarillo Haemulon sciurus, de aguas cubanas. Ciencias, Ser. 8. Invest. Mar., 27: 13-20.

Schellenberg, A. - 1930. Sübwasseramphipoden der Falklandinseln nebst Bemerkungen über Sternalkiemen. Zool. Anz., 91: 81-90.

Uéno, M. - 1966. Results of the speleological survey in South Korea, 1966. II. Gammarid Amphipoda found in subterranean waters of South Korea. Bull. Nat. Sci. Mus. Tokyo, 9(4): 501535.

Vonk, R. - 1988. Nuиanu curvata $\mathrm{n}$. sp. and Melita leiotelson n. sp. (Crustacea, Amphipoda) from beach interstitia on Curaçao. Uitg. natuurw. Studkring Suriname, 123: 185-198.

Received March 29, 2006. Accepted June 6, 2006.

Scient. ed.: E. Macpherson.

Published online November 17, 2006. 
